Article

\title{
Regioselective Hydroxylation of Rhododendrol by CYP102A1 and Tyrosinase
}

\author{
Chan Mi Park ${ }^{1}$, Hyun Seo Park ${ }^{1}$, Gun Su Cha ${ }^{2}$, Ki Deok Park ${ }^{3}$ and Chul-Ho Yun ${ }^{1, *(D)}$ \\ 1 School of Biological Sciences and Technology, Chonnam National University, 77 Yongbongro, \\ Gwangju 61186, Korea; cmpark0710@gmail.com (C.M.P.); hs6471@naver.com (H.S.P.) \\ 2 Namhae Garlic Research Institute, 2465-8 Namhaedaero, Namhae, Gyeongsangnamdo 52430, Korea; \\ gscha450@gmail.com \\ 3 Gwangju Center, Korea Basic Science Center, 77 Yongbongro, Gwangju 61186, Korea; kdpark@kbsi.re.kr \\ * Correspondence: chyun@chonnam.ac.kr
}

Received: 12 August 2020; Accepted: 24 September 2020; Published: 25 September 2020

check for updates

\begin{abstract}
Rhododendrol (RD) is a naturally occurring phenolic compound found in many plants. Tyrosinase (Ty) converts RD to RD-catechol and subsequently RD-quinone via two-step oxidation reactions, after which RD-melanin forms spontaneously from RD-quinone. RD is cytotoxic in melanocytes and lung cancer cells, but not in keratinocytes and fibroblasts. However, the function of RD metabolites has not been possible to investigate due to the lack of available high purity metabolites. In this study, an enzymatic strategy for RD-catechol production was devised using engineered cytochrome P450 102A1 (CYP102A1) and Ty, and the product was analyzed using high-performance liquid chromatography (HPLC), LC-MS, and NMR spectroscopy. Engineered CYP102A1 regioselectively produced RD-catechol via hydroxylation at the ortho position of RD. Although RD-quinone was subsequently formed by two step oxidation in Ty catalyzed reactions, L-ascorbic acid (LAA) inhibited RD-quinone formation and contributed to regioselective production of RD-catechol. When LAA was present, the productivity of RD-catechol by Ty was 5.3-fold higher than that by engineered CYP102A1. These results indicate that engineered CYP102A1 and Ty can be used as effective biocatalysts to produce hydroxylated products, and Ty is a more cost-effective biocatalyst for industrial applications than engineered CYP102A1.
\end{abstract}

Keywords: rhododendrol; cytochrome P450; tyrosinase; biocatalyst; hydroxylation; bioconversion

\section{Introduction}

Biocatalysts are biological systems, such as purified enzymes and whole cells, that can catalyze diverse chemical reactions. Enzymes can accept a wide range of molecules as substrates, and they exhibit high catalytic activities towards simple and complex chemicals. Consequently, they are used as biocatalysts in fields of chemical synthesis, biosensor production, and bioremediation. The biocatalysts can also be used to support several cascade reactions during organic compound synthesis. In particular, they are effective tools in the fine chemical and pharmaceutical industries because they exhibit chemo-, stereo-, and regioselectivity for chemical production in eco-friendly ways [1-5].

Generally, cytochrome P450 (P450 or CYP) enzymes catalyze the monooxygenase reaction (i.e., the insertion of one atom of molecular oxygen into a substrate and the reduction of the other oxygen atom to water) [6]. Required electrons for the reaction are provided from nicotinamide adenine dinucleotide cofactors (NADPH or NADH) via cytochrome $\mathrm{P} 450$ reductase (CPR). In addition, P450s catalyze diverse reactions such as $\mathrm{C}$-hydroxylation; N-oxidation; $\mathrm{N}-, \mathrm{O}-$, and S-dealkylation; $\mathrm{C}-\mathrm{C}$ bond cleavage; alcohol oxidation using diverse natural and non-natural compounds as substrates. Accordingly, CYPs have considerable potential as biocatalysts for novel drug development [7-9]. 
CYP102A1 from Bacillus megaterium (BM3) consists of the catalytic heme domain and the reductase domain in a single polypeptide [10]. CYP102A1 is more effective as a biocatalyst because of its high activity and solubility. The engineering of CYP102A1 through site-directed and random mutagenesis is reported to improve their activities toward various marketed drugs, steroids, and non-natural substrates. However, bioconversions via CYP102A1 have drawbacks on an industrial scale because they still require the use of a high-cost cofactor, NADPH [11-15].

Tyrosinase (Ty) is a copper-containing dioxygenase responsible for melanin formation in many organisms. Two copper ions, $\mathrm{CuA}$ and $\mathrm{CuB}$, coordinate six conserved histidine residues in the active sites $[16,17]$. Ty catalyzes the ortho-hydroxylation of monophenols to ortho-diphenols (catechols) via monophenolase activity, as well as the subsequent oxidation of ortho-diphenols to ortho-quinones via diphenolase activity. The highly reactive ortho-quinones convert to melanin spontaneously, and are involved in skin pigmentation and fruit and vegetable browning [18,19]. Ty has a considerable potential to synthesize bioactive catechol derivatives because of regioselective ortho-hydroxylation via monophenolase activity. However, Ty-associated melanin formation should be inhibited for industrial applications of the bioactive catechol derivatives [20,21]. Protein engineering using site-directed and random mutagenesis has been attempted to improve Ty's activity and substrate specificity [22,23]. Furthermore, the inhibition of Ty's diphenolase activity using catechol, NADH, and ascorbic acid was found to enhance the production of catechol derivatives [24-26]. For the industrial use of Ty to produce catechol compounds, the issue of further oxidation of catechol needs to be solved, but Ty seems to be a more cost-effective biocatalyst compared with $\mathrm{P} 450$ because it does not require the redox partners and NADPH.

Rhododendrol (RD, 4-(4-hydroxyphenyl)-2-butanol) is a naturally-occurring phenolic compound found in many plants such as Acer nikoense and Betula pubescens [27-29]. In melanocytes, RD is metabolized to RD-quinone via RD-catechol by a Ty-catalyzed reaction. Subsequent spontaneous reactions convert RD-quinone to melanin [30]. RD metabolites and RD-derived melanin generated by Ty cause oxidative stress and exhibit cytotoxicity in melanocytes [31]. RD is also cytotoxic in human lung cancer cells [32], but not in keratocytes and fibroblasts [33]. However, the bioactive or adverse effects of various RD metabolites are not well established because metabolites with high purity cannot be obtained on a large scale.

The aim of this study was to produce a highly pure RD-catechol product using engineered CYP102A1 and Ty as biocatalysts. We found that engineered CYP102A1 and Ty can catalyze the regioselective hydroxylation at the ortho position of $\mathrm{RD}$ to produce an RD-catechol with high selectivity (Figure 1). In addition, we compared the yield, final product concentration, and productivity for RD-catechol production by engineered CYP102A1 and Ty. To the best of our knowledge, this study is the first report of the production of a highly pure RD-catechol using engineered CYP102A1 and Ty.

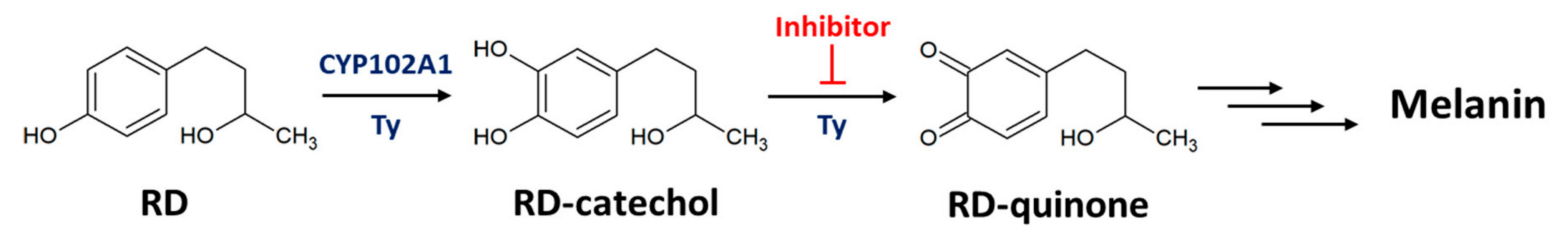

Figure 1. Scheme for rhododendrol (RD)-catechol production using cytochrome (CYP)102A1 and tyrosinase (Ty).

\section{Results and Discussion}

\subsection{Hydroxylation of RD by Engineered CYP102A1}

To find a CYP102A1 enzyme with a high activity towards RD, the catalytic activities of the CYP102A1 wild type (WT) and its engineered enzymes toward RD were investigated at a fixed substrate concentration of $200 \mu \mathrm{M}$ for $30 \mathrm{~min}$ of incubation. An NADPH regenerating system 
(NGS) was added to provide NADPH to the CYP102A1. The formation of RD-derived products by CYP102A1 was analyzed using high-performance liquid chromatography (HPLC). One major product was generated by engineered CYP102A1. The retention times of RD and its major product were 13.4 and $8.4 \mathrm{~min}$, respectively (Figure 2). Among this study's tested enzymes, WT CYP102A1 apparently could not oxidize RD, whereas ten engineered CYP102A1 showed high activity toward RD with more than $200 \mathrm{nmol}$ product/nmol P450. Engineered CYP102A1 \#16 (M16) was selected for further experiments because it showed the highest activity with $645 \mathrm{nmol}$ product/nmol P450 among the tested 45 engineered CYP102A1 (Figure S1).

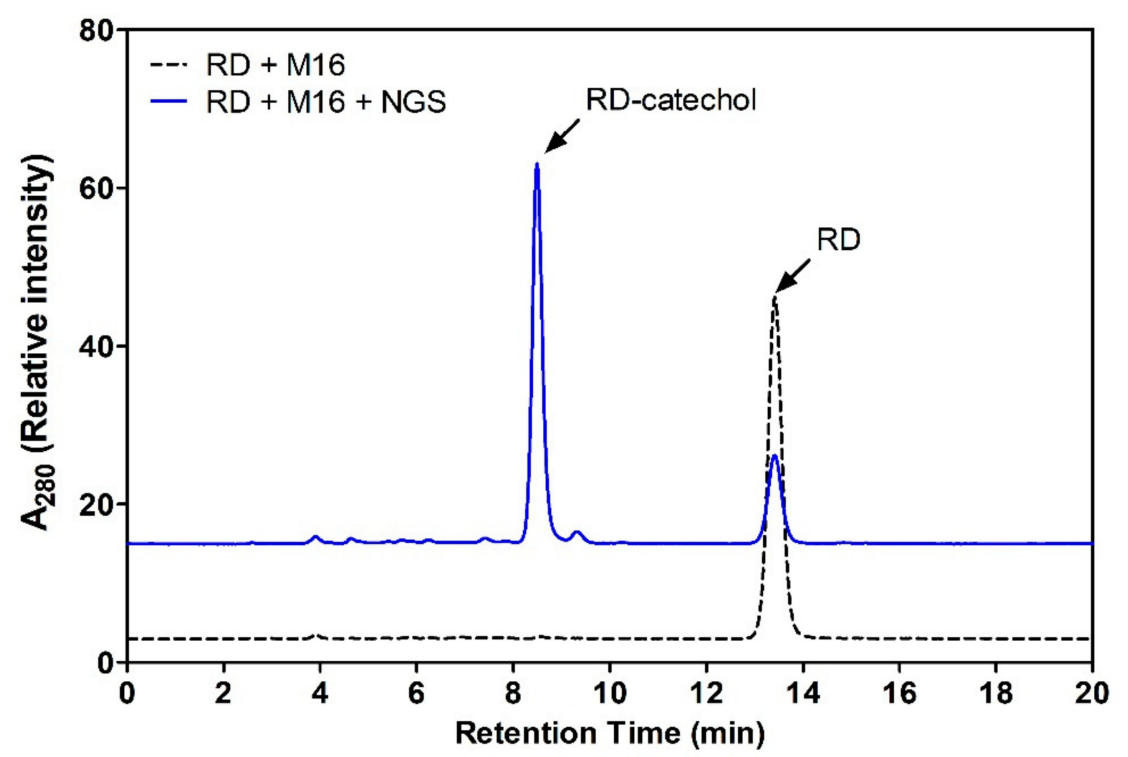

Figure 2. High-performance liquid chromatography (HPLC) chromatogram of RD and RD-catechol produced by engineered CYP102A1. The reaction mixtures contained $0.2 \mu \mathrm{M}$ M16 or $200 \mu \mathrm{M}$ RD with or without NADPH regenerating system (NGS). RD and RD-catechol were eluted at 13.4 and $8.4 \mathrm{~min}$, respectively.

M16 might produce RD-catechol or RD-resorcinol via hydroxylation at the ortho or meta positions of the RD's phenol ring. The major RD-derived product was identified using liquid chromatography-mass spectrometry (LC-MS) and nuclear magnetic resonance (NMR) spectroscopy. Although the molecular mass of RD is $166.22 \mathrm{~g} \cdot \mathrm{mol}^{-1}$, its mass to charge $(\mathrm{m} / \mathrm{z})$ value was calculated as 149 via LC-MS [34]. The $m / z$ value of the major product was 165 , which was 16 higher compared to RD (Figure S2). The ${ }^{1} \mathrm{H}$ and ${ }^{13} \mathrm{C}$ NMR spectra of RD and the product of M16 are shown in Figures S3-S6. Chemical structure and chemical shift assignments for RD and the product of M16 are shown in Figure S7 and Table S1. These results indicate that engineered CYP102A1 regioselectively produces an RD-catechol via hydroxylation at the ortho position.

\subsection{RD-Catechol Production by Engineered CYP102A1}

To increase the product concentration, M16 catalytic reactions were performed with various $\mathrm{RD}$ concentrations. RD-catechol production increased with $\mathrm{RD}$ concentration, and the productivity increased up to $200 \mu \mathrm{M} R \mathrm{RD}$ (Figure 3). In this condition, product yield, final product concentration, and productivity were $50.4 \%, 18.4 \mathrm{mg} \cdot \mathrm{L}^{-1}$, and $36.7 \mathrm{mg} \cdot \mathrm{L}^{-1} \cdot \mathrm{h}^{-1}$, respectively. The maximum RD-catechol was produced when RD concentration was $200 \mu \mathrm{M}$. The RD-catechol yield increased until $100 \mu \mathrm{M}$ RD, and then decreased. When RD concentration was $100 \mu \mathrm{M}$, the yield was highest at $53.8 \%$. These results indicate that M16 catalytic reactions below $200 \mu \mathrm{M}$ RD to produce RD-catechol is efficient Further purification steps might be needed to obtain highly pure RD-catechol, as the yield of RD-catechol was lower than 90\%. Although M16 can catalyze the regioselective hydroxylation 
of RD, M16 has limitations for industrial-scale applications due to its low yield and demand for NADPH. Therefore, it is necessary to develop alternative enzymes that can reduce cost and time of RD-catechol production.

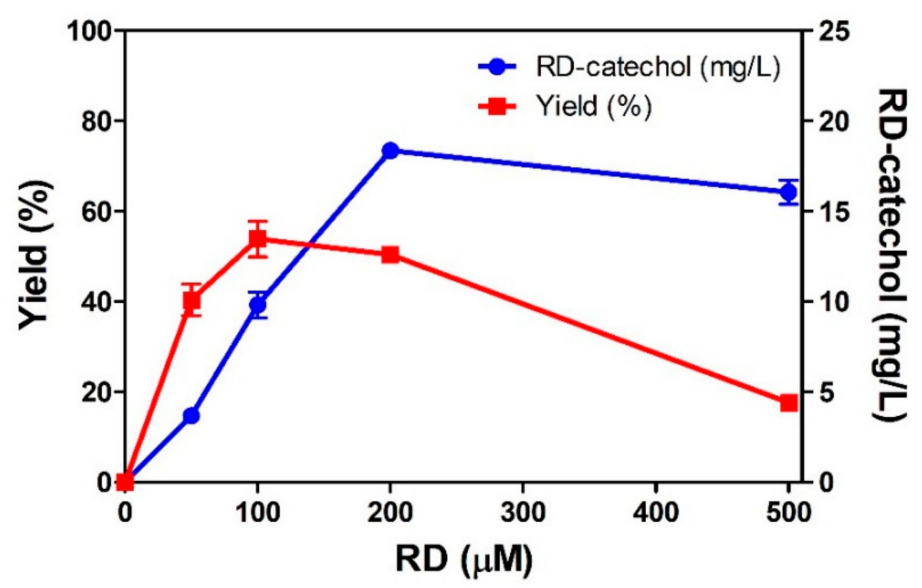

Figure 3. RD-catechol production by engineered CYP102A1 with increasing RD concentration. The reaction mixtures contained $0.2 \mu \mathrm{M}$ M16 with indicated RD concentration up to $500 \mu \mathrm{M}$, and NGS. RD-catechol produced by M16 was analyzed using HPLC.

\subsection{Inhibition of RD-Quinone Formation by Ascorbic Acid Analogs}

To develop an alternative enzyme to overcome the limitations of the CYP102A1 catalysis requiring $\mathrm{NADPH}$, we attempted to produce RD-catechol using Ty as a biocatalyst. Ty produces RD-catechol and RD-quinone from RD by catalyzing two-step oxidations of ortho-hydroxylation and the subsequent oxidation. RD-quinone is spontaneously converted to RD-melanin via a non-enzymatic pathway [30]. The absorbance of RD at $280 \mathrm{~nm}$ changed after the Ty-catalyzed reactions. Within $3 \mathrm{~min}$, absorbance near $400 \mathrm{~nm}$ increased, and absorbance at 280 and $340 \mathrm{~nm}$ also increased over time (Figure S8). This indicate that Ty rapidly produces RD-quinone and secondary quinone from RD [31]. Therefore, secondary oxidation by Ty should be inhibited to selectively produce RD-catechol. It has been reported that L-ascorbic acid (LAA) increases catechol production via the reduction of ortho-quinone to ortho-catechol [26]. In addition, LAA and D-ascorbic acid (DAA), an isomer of LAA, act as a suicide substrate against Ty in aerobic conditions [35]. In this study, we investigated the inhibitory effects of LAA, D-ascorbic acid (DAA), and dehydroascorbic acid (DHA), an oxidized form of LAA, on Ty-induced RD-quinone formation by monitoring absorbance at $400 \mathrm{~nm}$. The inhibitory effects of LAA and its analogs increased with increasing their concentrations. When Ty reacted with RD at $37^{\circ} \mathrm{C}$ for $30 \mathrm{~min}, 1 \mathrm{mM}$ LAA, DAA, and DHA inhibited RD-quinone formation by $86 \%, 95 \%$, and $8 \%$, respectively (Figure 4). The inhibitory effects of LAA and its analogs at $25^{\circ} \mathrm{C}$ were similar to those at $37^{\circ} \mathrm{C}$ (Figure S9). These results indicate that LAA analogs act as inhibitors of Ty, not as antioxidants for the reduction of ortho-quinone to ortho-catechol. In addition, it can be suggested that Ty has potential as an alternative biocatalyst for RD-catechol production because RD-quinone formation is inhibited in the presence of LAA analogs. 


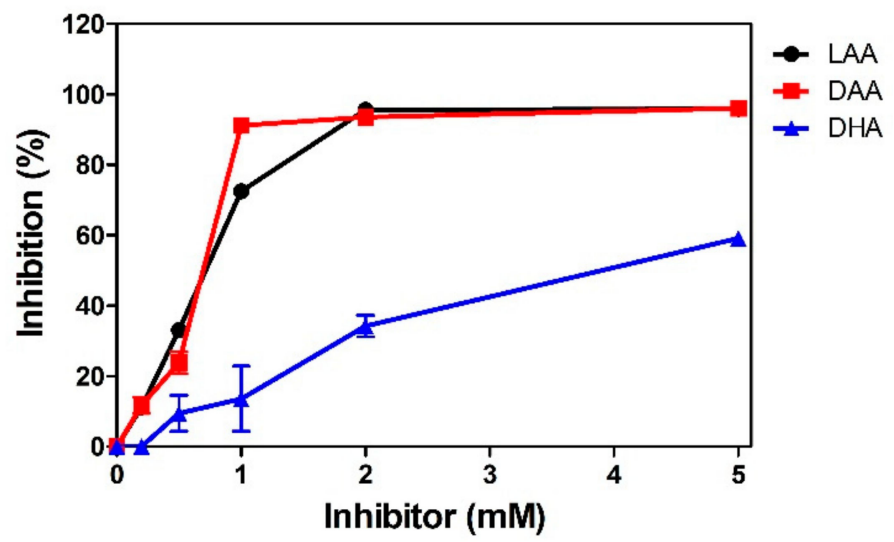

Figure 4. Inhibition of RD-quinone formation by L-ascorbic acid (LAA), D-ascorbic acid (DAA), and dehydroascorbic acid (DHA) at $37^{\circ} \mathrm{C}$.

\subsection{Regioselective Production of RD-Catechol by Ty}

For selective production of RD-catechol by Ty, LAA was selected as an inhibitor of its diphenolase activity. Ty produced one major product at a temperature range of $25-45^{\circ} \mathrm{C}$ when the reaction mixture contained Ty, RD, and LAA. RD's conversion to the product by Ty was the highest at $37^{\circ} \mathrm{C}$ (Figure S10). In addition, production of the major product by Ty was investigated when 5-100 mM LAA contained in reaction mixture at $37^{\circ} \mathrm{C}$. RD's conversion by Ty increased over time and was saturated within $30 \mathrm{~min}$. Ty produced the highest product of $84.1 \mathrm{mg} \cdot \mathrm{L}^{-1}$ when the reaction mixture containing $10 \mathrm{mM}$ LAA was incubated at $37^{\circ} \mathrm{C}$ for $30 \mathrm{~min}$ (Figure 5).

(a)

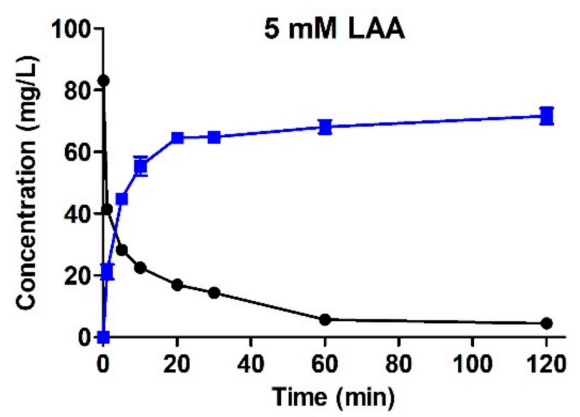

(c)

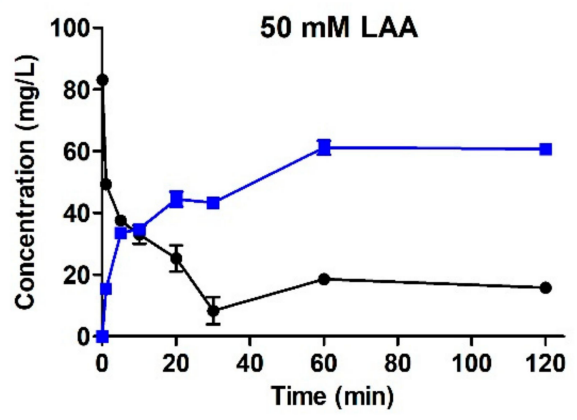

(b)

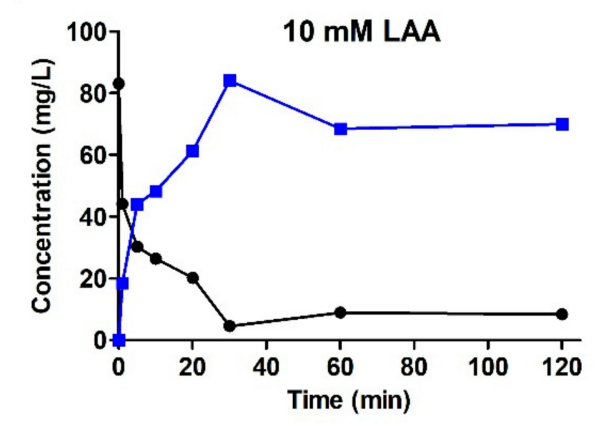

(d)

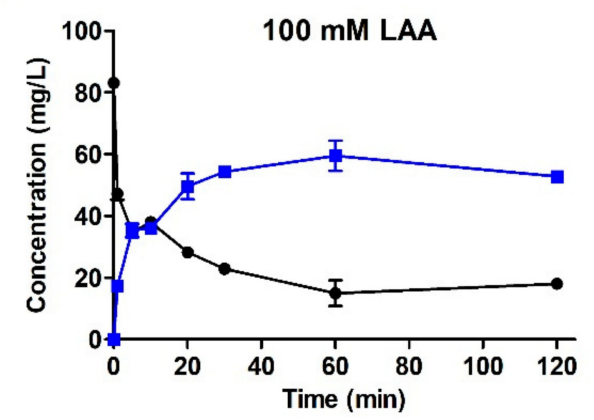

Figure 5. Effect of LAA concentration on the production of RD-catechol. The reaction mixtures contained five units of Ty and $500 \mu \mathrm{M}$ RD in $250 \mu \mathrm{L}$ of a $100 \mathrm{mM}$ potassium phosphate buffer ( $\mathrm{pH}$ 6.5) with 5 (a), 10 (b), 50 (c), or $100 \mathrm{mM}$ LAA (d). The reaction mixtures were incubated at $37^{\circ} \mathrm{C}$ for

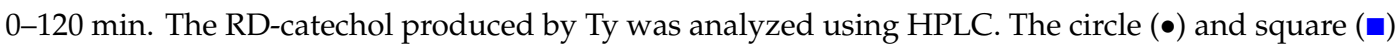
lines indicate concentration of RD and RD-catechol, respectively. 
The major product of Ty eluted at 8.4 min on HPLC (Figure S11), which was the same retention time with the major product of M16 (Figure 2). To identify Ty's product, LC-MS and NMR analyses were performed. The $m / z$ value of this product was 165 on LC-MS, which was 16 higher compared to the RD (Figure S12). The ${ }^{1} \mathrm{H}$ and ${ }^{13} \mathrm{C}$ NMR spectra of Ty's product were the same as those of M16's product (Figures S13 and S14). These results indicate that Ty catalyzes the ortho-hydroxylation to regioselectively produce RD-catechol when LAA acts as an inhibitor of Ty's diphenolase activity.

To increase RD-catechol production, Ty catalytic reactions were performed at high RD concentrations. Ty's RD-catechol production increased with RD concentration, and it became saturated from $2 \mathrm{mM}$ RD. In this condition, yield, product concentration, and productivity were $69.3 \%, 252 \mathrm{mg} \cdot \mathrm{L}^{-1}$, and $505 \mathrm{mg} \cdot \mathrm{L}^{-1} \cdot \mathrm{h}^{-1}$, respectively. The RD-catechol yield increased until $500 \mu \mathrm{M}$ and then decreased. When the RD concentration was $500 \mu \mathrm{M}$, the yield was highest at $93.9 \%$. The final product concentration and productivity were $85.6 \mathrm{mg} \cdot \mathrm{L}^{-1}$ and $171 \mathrm{mg} \cdot \mathrm{L}^{-1} \cdot \mathrm{h}^{-1}$, respectively (Figure 6). These results suggest that Ty can be used as an alternative biocatalyst for the selective production of RD-catechol with high productivity.

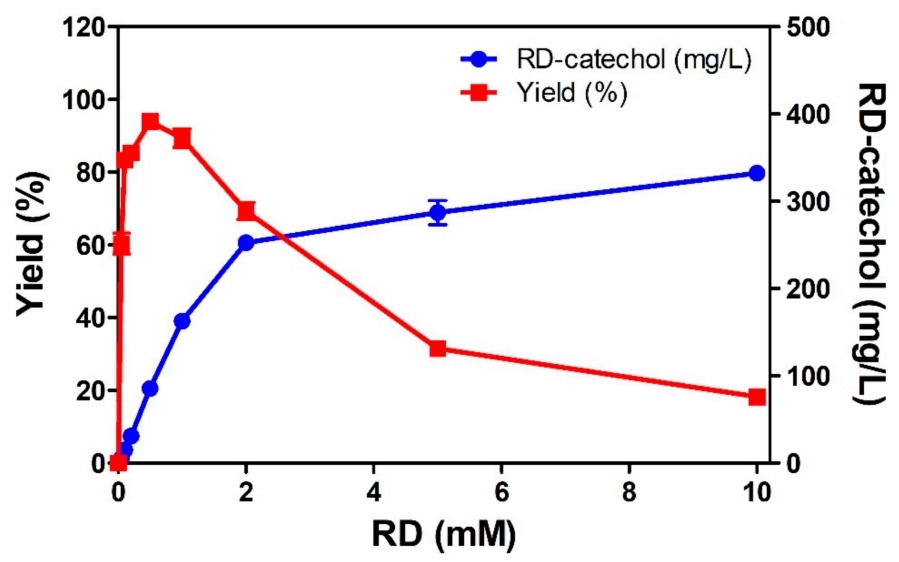

Figure 6. RD-catechol production by Ty with increasing RD concentration. The reaction mixtures contained five units of Ty, indicated concentrations of RD, and 10 mM LAA. RD-catechol produced by Ty was analyzed using HPLC.

The production capability of enzymes is evaluated in terms of productivity $\left(\mathrm{mg} \cdot \mathrm{L}^{-1} \cdot \mathrm{h}^{-1}\right)$ and final product concentration $\left(\mathrm{mg} \cdot \mathrm{L}^{-1}\right)$. For pharmaceutical production, the estimated minimum productivity and final product concentration are $1 \mathrm{mg} \cdot \mathrm{L}^{-1} \cdot \mathrm{h}^{-1}$ and $100 \mathrm{mg} \cdot \mathrm{L}^{-1}$, respectively [36-39]. The production abilities of M16 and Ty were compared when the RD concentration was $500 \mu \mathrm{M}$ (Table 1). In this condition, both biocatalysts produced mainly RD-catechol, and their selectivity values exceeded 90\%. Ty yielded 93.9\% RD-catechol from RD, whereas M16 produced 17.6\% RD-catechol from RD. The productivities of M16 and Ty were $32.1 \mathrm{mg} \cdot \mathrm{L}^{-1} \cdot \mathrm{h}^{-1}$ and $171 \mathrm{mg} \cdot \mathrm{L}^{-1} \cdot \mathrm{h}^{-1}$, respectively. These results indicate that Ty produced 5.3 times more RD-catechol compared with M16. In addition, one-pot synthesis of RD-catechol by Ty is possible without additional purification steps when the RD concentration is $500 \mu \mathrm{M}$.

Table 1. Comparison of production abilities of engineered CYP102A1 and Ty.

\begin{tabular}{ccccc}
\hline Biocatalyst & Selectivity (\%) & Yield (\%) & $\begin{array}{c}\text { Product Concentration } \\
\mathbf{( m g} \cdot \mathbf{L}^{-\mathbf{1}}\end{array}$ & $\begin{array}{c}\text { Productivity } \\
\mathbf{( m g} \cdot \mathbf{L}^{\mathbf{- 1}} \cdot \mathbf{h}\end{array}$ \\
\hline CYP102A1 $^{\mathbf{1}}{ }^{1}$ & $93.5 \pm 1.4$ & $17.6 \pm 0.7$ & $16.1 \pm 0.7$ & 32.1 \\
Ty $^{2}$ & $90.4 \pm 0.4$ & $93.9 \pm 1.8$ & $85.6 \pm 1.6$ & 171 \\
\hline
\end{tabular}

${ }^{1}$ The reaction mixture contained $0.2 \mu \mathrm{M}$ M16, $500 \mu \mathrm{M}$ RD, and NGS in $250 \mu \mathrm{L}$ of $100 \mathrm{mM}$ potassium phosphate buffer (pH 7.4) and was incubated at $37^{\circ} \mathrm{C}$ for $30 \mathrm{~min}$ (Figure 3). ${ }^{2}$ The reaction mixture contained five units of Ty, $500 \mu \mathrm{M}$ RD, and $10 \mathrm{mM}$ LAA in $250 \mu \mathrm{L}$ of $100 \mathrm{mM}$ potassium phosphate buffer (pH 6.5) and was incubated at $37^{\circ} \mathrm{C}$ for 30 min (Figure 6). 
In conclusion, we found that engineered CYP102A1 and Ty can catalyze the regioselective hydroxylation of RD and produce RD-catechol. Additionally, LAA and its analogs inhibit Ty's diphenolase activity and contribute to selective RD-catechol production by inhibiting RD-quinone and melanin formation. Compared with engineered CYP102A1, Ty can reduce the cost and time of RD-catechol production because its productivity and yield were quite high at $171 \mathrm{mg} \cdot \mathrm{L}^{-1} \cdot \mathrm{h}^{-1}$ and $93.9 \%$, and it does not require high-cost NADPH. Taken together, these findings indicate that engineered CYP102A1 and Ty can be used as efficient biocatalysts and immobilized systems to make hydroxylated products. Ty is a cost-effective biocatalyst and is more appropriate for industrial applications compared with engineered CYP102A1.

\section{Materials and Methods}

\subsection{Materials}

Glucose-6-phosphate dehydrogenase (G6PDH, from yeast), glucose-6-phosphate (G6P), NADP ${ }^{+}$, Ty (from Agaricus bisporus), LAA, DAA, and DHA were obtained from Sigma-Aldrich (St. Louis, MO, USA). RD was obtained from Tokyo Chemical Industry (Tokyo, Japan). All the other chemicals were of analytical grade.

\subsection{Preparation of Engineered CYP102A1}

The engineered CYP102A1 enzymes used in this study are known to have high activities toward non-natural substrates, and they were constructed by site-directed and random mutagenesis [14,40-42]. The changed amino acid residues of engineered CYP102A1 are shown in Table S2. CYP102A1 WT and engineered enzymes were expressed in Escherichia coli and were purified as previously described [40]. The plasmid of CYP102A1 enzymes (in pCW vector) was transformed to E. coli $\mathrm{DH} 5 \alpha \mathrm{F}^{\prime}$-IQ strain. The transformed cells were grown overnight in $5 \mathrm{~mL}$ of Luria-Bertani (LB) broth with ampicillin $\left(100 \mu \mathrm{g} \cdot \mathrm{mL}^{-1}\right)$ at $37^{\circ} \mathrm{C}$. Precultured cells were inoculated to $250 \mathrm{~mL}$ of terrific broth (TB) containing ampicillin $\left(100 \mu \mathrm{g} \cdot \mathrm{mL}^{-1}\right)$ and were grown at $37^{\circ} \mathrm{C}$ with shaking at $250 \mathrm{rpm}$ until reaching 0.8 of $\mathrm{A}_{600}$. The expression of CYP102A1 enzymes was induced by adding $0.5 \mathrm{mM}$ isopropyl $\beta$-D-1-thiogalactopyranoside (IPTG) and $1 \mathrm{mM} \delta$-aminolevulinic acid. The culture was grown at $30{ }^{\circ} \mathrm{C}$ with shaking at $190 \mathrm{rpm}$ for $24 \mathrm{~h}$. The cells were harvested by centrifugation at $5000 \times g$ for $15 \mathrm{~min}$. The cell pellet was resuspended in a TES buffer (100 mM Tris-HCl, pH 7.6, $0.5 \mathrm{mM}$ EDTA, and $500 \mathrm{mM}$ sucrose) and lysed by sonication. After the lysate was centrifuged at $100,000 \times g$ for $90 \mathrm{~min}$ at $4{ }^{\circ} \mathrm{C}$, the soluble cytosolic fraction was collected and used for the activity assay. The CYP102A1 enzymes' concentration in the cytosolic fraction was determined from the CO-difference spectra using $\varepsilon=91 \mathrm{mM}^{-1} \cdot \mathrm{cm}^{-1}[43]$.

\subsection{Hydroxylation of RD by Engineered CYP102A1}

The catalytic activity of RD hydroxylation by CYP102A1 was measured as described previously [44]. To measure the activity of the CYP102A1 WT and engineered enzymes, the reaction mixtures contained $0.2 \mu \mathrm{M}$ enzyme, $200 \mu \mathrm{M}$ RD, and NGS in $250 \mu \mathrm{L}$ of $100 \mathrm{mM}$ potassium phosphate buffer ( $\mathrm{pH}$ 7.4). To investigate the effects of RD concentration on RD-catechol production by M16, the reaction mixtures contained $0.2 \mu \mathrm{M}$ M16 and NGS in $250 \mu \mathrm{L}$ of $100 \mathrm{mM}$ potassium phosphate buffer with $0,50,100,200$, or $500 \mu \mathrm{M}$ RD. The reactions were initiated by adding NGS $\left(10 \mathrm{mM} \mathrm{G6P}, 2 \mathrm{mM} \mathrm{NADP}^{+}\right.$, and $0.5 \mu \mathrm{g}$ yeast G6PDH in $250 \mu \mathrm{L}$ ) and were stopped with $25 \mu \mathrm{L}$ of $1 \mathrm{~N} \mathrm{HCl}$ containing $2 \mathrm{M} \mathrm{NaCl}$ and $600 \mu \mathrm{L}$ of ice-cold ethyl acetate after incubating for $30 \mathrm{~min}$ at $37^{\circ} \mathrm{C}$. After centrifugation of the samples at $3000 \mathrm{rpm}$ for $10 \mathrm{~min}$, an organic layer was transferred to a new tube and evaporated under nitrogen gas. The samples were dissolved using $180 \mu \mathrm{L}$ of mobile phase. The reaction products were analyzed using an SPD-20A UV-Visible detector (Shimadzu, Kyoto, Japan) on an LC-20AD HPLC (Shimadzu, Kyoto, Japan). The products were separated by a Gemini C18 column $(150 \times 4.6 \mathrm{~mm}, 5 \mu \mathrm{m}$; Phenomenex, Torrance, CA, USA) with a mobile phase of $10 \mathrm{mM}$ formic acid in water/methanol $(60: 40, v / v)$. The sample was 
injected with $30 \mu \mathrm{L}$ using a SIL-20A auto sampler (Shimadzu, Kyoto, Japan), and the flow rate was $0.5 \mathrm{~mL} / \mathrm{min}$. The RD and products were detected at $280 \mathrm{~nm}$.

\subsection{Inhibition of RD-Quinone Formation}

RD-quinone formation by Ty was monitored using a UV-160 IPC UV-Visible spectrophotometer (Shimadzu, Kyoto, Japan). The reaction mixtures contained 20 units of Ty, $500 \mu \mathrm{M}$ RD, and $1 \mathrm{mM}$ LAA, DAA, or DHA in $1 \mathrm{~mL}$ of $100 \mathrm{mM}$ of potassium phosphate buffer $(\mathrm{pH} 6.5)$, and were incubated at 25 or $37^{\circ} \mathrm{C}$ for $30 \mathrm{~min}$. The inhibitory effects were expressed as percentage of the absorbance decreased relative to the absorbance at $400 \mathrm{~nm}$ of the sample without the inhibitor.

\subsection{Production of RD-Catechol by Tyrosinase}

The Ty reaction mixtures contained five units of Ty and $500 \mu \mathrm{M}$ RD in $250 \mu \mathrm{L}$ of $100 \mathrm{mM}$ potassium phosphate buffer ( $\mathrm{pH} 6.5$ ) with 5, 10, 50, or $100 \mathrm{mM} \mathrm{LAA}$, and were incubated at $37^{\circ} \mathrm{C}$ for $0,1,5,10$, 20, 30, 60, or $120 \mathrm{~min}$. To increase RD-catechol production, five units of Ty; 0, 0.05, 0.1, 0.2, 0.5, 1, 2, 5, or $10 \mathrm{mM} \mathrm{RD}$; and $10 \mathrm{mM}$ LAA were incubated in $250 \mu \mathrm{L}$ of $100 \mathrm{mM}$ potassium phosphate buffer $(\mathrm{pH}$ 6.5) at $37^{\circ} \mathrm{C}$ for $30 \mathrm{~min}$. The reaction mixtures were initiated by adding enzyme and were stopped with $25 \mu \mathrm{L}$ of $1 \mathrm{~N} \mathrm{HCl}$ containing $2 \mathrm{M} \mathrm{NaCl}$ and $600 \mu \mathrm{L}$ of ice-cold ethyl acetate. After centrifugation at $1000 \times g$ for $10 \mathrm{~min}$, an organic layer was transferred to a new tube and evaporated under nitrogen gas. The samples were dissolved using $180 \mu \mathrm{L}$ of mobile phase, and the products were analyzed via HPLC as described above.

\subsection{Identification of RD-Catechol by LC-MS}

To investigate the mass of the major product, we used a CYP102A1 reaction mixture containing $0.2 \mu \mathrm{M}$ M16, $500 \mu \mathrm{M}$ RD, and NGS in $250 \mu \mathrm{L}$ of $100 \mathrm{mM}$ potassium phosphate buffer ( $\mathrm{pH}$ 7.4). The Ty reaction mixture contained five units of Ty, $500 \mu \mathrm{M}$ RD, and $10 \mathrm{mM}$ LAA in $250 \mu \mathrm{L}$ of $100 \mathrm{mM}$ potassium phosphate buffer ( $\mathrm{pH}$ 6.5). These mixtures were incubated at $37^{\circ} \mathrm{C}$ for $30 \mathrm{~min}$. Injection samples were created as described above. The mass values of $\mathrm{RD}$ and its products were analyzed using a TSQ Quantum ${ }^{\mathrm{TM}}$ Access MAX Triple Quadrupole Mass Spectrometer on an Accela 1250 HPLC system (Thermo Fisher Scientific, Waltham, MA, USA). The samples were separated on a ZORBAX SB-C18 column $(250 \mathrm{~mm} \times 4.6 \mathrm{~mm}$ i.d. $5 \mu \mathrm{m}$; Agilent, Santa Clara, CA, USA) at a flow rate of $1 \mathrm{~mL} / \mathrm{min}$. The mobile phases were (A) $10 \mathrm{mM}$ formic acid in water and (B) methanol. The isocratic flow of mobile phase was (A) $60 \%$ : (B) $40 \%$ on HPLC. The injection volume was $10 \mu \mathrm{L}$. The mass spectra were recorded by electrospray ionization in positive mode to identify the RD metabolites. The collision energy and scan rate were $10 \mathrm{~V}$ and $0.5 \mathrm{spectra} / \mathrm{s}$, respectively.

\subsection{Identification of RD-Catechol by NMR Spectroscopy}

To identify the products of engineered CYP102A1 and Ty, reaction mixtures and injection samples were prepared as described above. The samples were separated using HPLC, and the major product eluted at $8.4 \mathrm{~min}$ was collected. The collected samples were dried using a freezing drier (Operon, Gimpo, Korea). NMR experiments were performed at $25^{\circ} \mathrm{C}$ on a Varian VNMRS $600 \mathrm{MHz}$ NMR spectrometer (Varian Inc., Palo Alto, CA, USA) equipped with a carbon-enhanced cryogenic probe. Methanol- $\mathrm{d}_{4}$ was used as the solvent, and the chemical shifts for the proton NMR spectra were measured in parts per million (ppm) relative to tetramethylsilane. All of the NMR experiments were carried out with standard pulse sequences in the VNMRJ (v. 3.2) library and processed with the same software (Agilent, Santa Clara, CA, USA).

\subsection{Statistical Analysis}

All experiments were performed three times. The values are presented as means with a standard error of mean (SEM). 
Supplementary Materials: The following are available online at http://www.mdpi.com/2073-4344/10/10/1114/s1: Figure S1: Total turnover numbers of engineered CYP102A1 enzymes. Figure S2: Total ion chromatography and mass scan of RD and product of M16. Figure S3: ${ }^{1} \mathrm{H}$ NMR spectra of RD (a) and the major product of M16 (b), Figure S4: Comparison of aromatic region in the ${ }^{1} \mathrm{H}$ NMR spectra of RD (a) and the major product of M16 (b), Figure S5: ${ }^{13} \mathrm{C}$ NMR spectra of RD (a) and the major product of M16 (b), Figure S6: Comparison of quaternary peaks in the ${ }^{13} \mathrm{C}$ NMR spectra of RD (a) and the major product of M16 (b), Figure S7: Chemical structures of RD and RD-catechol, Figure S8: RD-quinone formation by Ty was analyzed by UV-Vis spectrophotometer, Figure S9: Inhibition of RD-quinone formation by L-ascorbic acid (LAA), D-ascorbic acid (DAA), and dehydroascorbic acid (DHA) at $25^{\circ} \mathrm{C}$, Figure S10: Effects of temperature on conversion rate of CYP102A1 and Ty, Figure S11: HPLC chromatogram of RD and RD-catechol produced by Ty, Figure S12: Total ion chromatography and mass scan of RD and product of Ty, Figure S13: ${ }^{1} \mathrm{H}$ NMR spectra of products of M16 (a) and Ty (b), Figure S14: ${ }^{13} \mathrm{C}$ NMR spectra of products of M16 (a) and Ty (b), Table S1: ${ }^{1} \mathrm{H}$ and ${ }^{13} \mathrm{C}$ chemical shifts of RD and RD-catechol, Table S2: Changed amino acid residues of the engineered CYP102A1 used in this study.

Author Contributions: Conceptualization, C.M.P., G.S.C., and C.-H.Y.; validation, C.M.P., H.S.P., and G.S.C.; formal analysis, C.M.P.; investigation, C.M.P., H.S.P., G.S.C., and K.D.P.; writing-original draft preparation, C.M.P.; writing-review and editing, C.-H.Y.; visualization, C.M.P.; supervision, C.-H.Y.; funding acquisition, C.M.P. and C.-H.Y. All authors have read and agreed to the published version of the manuscript.

Funding: This research was supported by Basic Science Research Program through the National Research Foundation of Korea (NRF) funded by the Ministry of Education (2020R1I1A1A01055345) and the Basic Research Lab Program (NRF-2018R1A4A1023882), National Research Foundation of Korea, Republic of Korea.

Conflicts of Interest: The authors declare no conflict of interest.

\section{References}

1. Schmid, A.; Dordick, J.S.; Hauer, B.; Kiener, A.; Wubbolts, M.; Witholt, B. Industrial biocatalysis today and tomorrow. Nature 2001, 409, 258-268. [CrossRef] [PubMed]

2. Torres, J.A.; Nogueirab, F.G.E.; Silvac, M.C.; Lopes, J.H.; Tavaresa, T.S.; Ramalho, T.C.; Corrêaa, A.D. Novel eco-friendly biocatalyst: Soybean peroxidase immobilized onto activated carbon obtained from agricultural waste. RSC Adv. 2017, 7, 16460-16466. [CrossRef]

3. Choi, J.M.; Han, S.S.; Kim, H.S. Industrial applications of enzyme biocatalysis: Current status and future aspects. Biotechnol. Adv. 2015, 33, 1443-1454. [CrossRef] [PubMed]

4. Nitti, A.; Bianchi, G.; Po, R.; Swager, T.M.; Pasini, D. Domino Direct Arylation and Cross-Aldol for Rapid Construction of Extended Polycyclic pi-Scaffolds. J. Am. Chem. Soc. 2017, 139, 8788-8791. [CrossRef] [PubMed]

5. Osburn, P.L.; Bergbreiter, D.E. Molecular engineering of organic reagents and catalysts using soluble polymers. Prog. Polym. Sci. 2001, 26, 2015-2081. [CrossRef]

6. Nelson, D.R. The cytochrome p450 homepage. Hum. Genom. 2009, 4, 59-65. [CrossRef]

7. Guengerich, F.P. Common and uncommon cytochrome P450 reactions related to metabolism and chemical toxicity. Chem. Res. Toxicol. 2001, 14, 611-650. [CrossRef] [PubMed]

8. Guengerich, F.P.; Munro, A.W. Unusual cytochrome p450 enzymes and reactions. J. Biol. Chem. 2013, 288, 17065-17073. [CrossRef]

9. Urlacher, V.B.; Girhard, M. Cytochrome P450 Monooxygenases in Biotechnology and Synthetic Biology. Trends Biotechnol. 2019, 37, 882-897. [CrossRef]

10. Munro, A.W.; Daff, S.; Coggins, J.R.; Lindsay, J.G.; Chapman, S.K. Probing electron transfer in flavocytochrome P-450 BM3 and its component domains. Eur. J. Biochem. 1996, 239, 403-409. [CrossRef]

11. Lussenburg, B.M.A.; Babel, L.C.; Vermeulen, N.P.E.; Commandeur, J.N.M. Evaluation of alkoxyresorufins as fluorescent substrates for cytochrome P450 BM3 and site-directed mutants. Anal. Biochem. 2005, 341, 148-155. [CrossRef] [PubMed]

12. Yun, C.H.; Kim, K.H.; Kim, D.H.; Jung, H.C.; Pan, J.G. The bacterial P450 BM3: A prototype for a biocatalyst with human P450 activities. Trends Biotechnol. 2007, 25, 289-298. [CrossRef] [PubMed]

13. Whitehouse, C.J.; Bell, S.G.; Wong, L.L. P450 (BM3) (CYP102A1): Connecting the dots. Chem. Soc. Rev. 2012, 41, 1218-1260. [CrossRef] [PubMed]

14. Kang, J.Y.; Ryu, S.H.; Park, S.H.; Cha, G.S.; Kim, D.H.; Kim, K.H.; Hong, A.W.; Ahn, T.; Pan, J.G.; Joung, Y.H.; et al. Chimeric cytochromes $\mathrm{P} 450$ engineered by domain swapping and random mutagenesis for producing human metabolites of drugs. Biotechnol. Bioeng. 2014, 111, 1313-1322. [CrossRef] [PubMed] 
15. Urlacher, V.B.; Eiben, S. Cytochrome P450 monooxygenases: Perspectives for synthetic application. Trends Biotechnol. 2006, 24, 324-330. [CrossRef] [PubMed]

16. Ismaya, W.T.; Rozeboom, H.J.; Weijn, A.; Mes, J.J.; Fusetti, F.; Wichers, H.J.; Dijkstra, B.W. Crystal structure of Agaricus bisporus mushroom tyrosinase: Identity of the tetramer subunits and interaction with tropolone. Biochemistry 2011, 50, 5477-5486. [CrossRef] [PubMed]

17. Ramsden, C.A.; Riley, P.A. Tyrosinase: The four oxidation states of the active site and their relevance to enzymatic activation, oxidation and inactivation. Bioorg. Med. Chem. 2014, 22, 2388-2395. [CrossRef]

18. Pillaiyar, T.; Namasivayam, V.; Manickam, M.; Jung, S.H. Inhibitors of Melanogenesis: An Updated Review. J. Med. Chem. 2018, 61, 7395-7418. [CrossRef]

19. Goldfeder, M.; Kanteev, M.; Adir, N.; Fishman, A. Influencing the monophenolase/diphenolase activity ratio in tyrosinase. Biochim. Biophys. Acta 2013, 1834, 629-633. [CrossRef]

20. Halaouli, S.; Asther, M.; Sigoillot, J.C.; Hamdi, M.; Lomascolo, A. Fungal tyrosinases: New prospects in molecular characteristics, bioengineering and biotechnological applications. J. Appl. Microbiol. 2006, 100, 219-232. [CrossRef]

21. Hernandez-Romero, D.; Sanchez-Amat, A.; Solano, F. A tyrosinase with an abnormally high tyrosine hydroxylase/dopa oxidase ratio. FEBS J. 2006, 273, 257-270. [CrossRef] [PubMed]

22. Shuster Ben-Yosef, V.; Sendovski, M.; Fishman, A. Directed evolution of tyrosinase for enhanced monophenolase/diphenolase activity ratio. Enzym. Microb. Technol. 2010, 47, 372-376. [CrossRef]

23. Molloy, S.; Nikodinovic-Runic, J.; Martin, L.B.; Hartmann, H.; Solano, F.; Decker, H.; O'Connor, K.E. Engineering of a bacterial tyrosinase for improved catalytic efficiency towards D-tyrosine using random and site directed mutagenesis approaches. Biotechnol. Bioeng. 2013, 110, 1849-1857. [CrossRef] [PubMed]

24. Lee, N.; Kim, E.J.; Kim, B.G. Regioselective hydroxylation of trans-resveratrol via inhibition of tyrosinase from Streptomyces avermitilis MA4680. ACS Chem. Biol. 2012, 7, 1687-1692. [CrossRef]

25. Lee, N.; Lee, S.H.; Baek, K.; Kim, B.G. Heterologous expression of tyrosinase (MelC2) from Streptomyces avermitilis MA4680 in E. coli and its application for ortho-hydroxylation of resveratrol to produce piceatannol. Appl. Microbiol. Biotechnol. 2015, 99, 7915-7924. [CrossRef]

26. Lee, S.H.; Baek, K.; Lee, J.E.; Kim, B.G. Using tyrosinase as a monophenol monooxygenase: A combined strategy for effective inhibition of melanin formation. Biotechnol. Bioeng. 2016, 113, 735-743. [CrossRef]

27. Tallent, W.H. d-Betuligenol from Rhododendron maximum L. J. Org. Chem. 1964, 29, 988-989. [CrossRef]

28. Fujita, T.; Hatamoto, H.; Iwasaki, T.; Takafuji, S.I. Bioconversion of rhododendrol by Acer nikoense. Phytochemistry 1995, 39, 1085-1089. [CrossRef]

29. Pan, H.; Lundgren, L.N. Rhododendrol glycosides and phenyl glucoside esters from inner bark of Betula pubescens. Phytochemistry 1994, 36, 79-83. [CrossRef]

30. Ito, S.; Wakamatsu, K. Biochemical Mechanism of Rhododendrol-Induced Leukoderma. Int. J. Mol. Sci. 2018, $19,552$.

31. Ito, S.; Ojika, M.; Yamashita, T.; Wakamatsu, K. Tyrosinase-catalyzed oxidation of rhododendrol produces 2-methylchromane-6,7-dione, the putative ultimate toxic metabolite: Implications for melanocyte toxicity. Pigment Cell Melanoma Res. 2014, 27, 744-753. [CrossRef]

32. Yang, E.J.; An, J.H.; Son, Y.K.; Yeo, J.H.; Song, K.S. The Cytotoxic Constituents of Betula platyphylla and their Effects on Human Lung A549 Cancer Cells. Nat. Prod. Sci. 2018, 24, 219-224. [CrossRef]

33. Yang, L.; Yang, F.; Wataya-Kaneda, M.; Tanemura, A.; Tsuruta, D.; Katayama, I. 4-(4-Hydroroxyphenyl)-2-butanol (rhododendrol) activates the autophagy-lysosome pathway in melanocytes: Insights into the mechanisms of rhododendrol-induced leukoderma. J. Dermatol. Sci. 2015, 77, 182-185. [CrossRef]

34. Kasamatsu, S.; Hachiya, A.; Nakamura, S.; Yasuda, Y.; Fujimori, T.; Takano, K.; Moriwaki, S.; Hase, T.; Suzuki, T.; Matsunaga, K. Depigmentation caused by application of the active brightening material, rhododendrol, is related to tyrosinase activity at a certain threshold. J. Dermatol. Sci. 2014, 76, 16-24. [CrossRef] [PubMed]

35. Munoz-Munoz, J.L.; Garcia-Molina, F.; García-Ruiz, P.A.; Varon, R.; Tudela, J.; García-Cánovas, F.; Rodriguez-Lopez, J.N. Stereospecific inactivation of tyrosinase by l- and d-ascorbic acid. Biochim. Biophys. Acta. Proteins Proteom. 2009, 1794, 244-253. [CrossRef] [PubMed]

36. Porter, J.L.; Rusli, R.A.; Ollis, D.L. Directed Evolution of Enzymes for Industrial Biocatalysis. ChemBioChem 2016, 17, 197-203. [CrossRef] [PubMed] 
37. Julsing, M.K.; Cornelissen, S.; Buhler, B.; Schmid, A. Heme-iron oxygenases: Powerful industrial biocatalysts? Curr. Opin. Chem. Biol. 2008, 12, 177-186. [CrossRef]

38. Pollard, D.J.; Woodley, J.M. Biocatalysis for pharmaceutical intermediates: The future is now. Trends Biotechnol. 2007, 25, 66-73. [CrossRef]

39. Straathof, A.J.J.; Panke, S.; Schmid, A. The production of fine chemicals by biotransformations. Curr. Opin. Biotech. 2002, 13, 548-556. [CrossRef]

40. Kim, D.H.; Kim, K.H.; Kim, D.H.; Liu, K.H.; Jung, H.C.; Pan, J.G.; Yun, C.H. Generation of human metabolites of 7-ethoxycoumarin by bacterial cytochrome P450 BM3. Drug Metab. Dispos. 2008, 36, 2166-2170. [CrossRef]

41. Park, S.H.; Kim, D.H.; Kim, D.; Kim, D.H.; Jung, H.C.; Pan, J.G.; Ahn, T.; Kim, D.; Yun, C.H. Engineering bacterial cytochrome P450 (P450) BM3 into a prototype with human P450 enzyme activity using indigo formation. Drug Metab. Dispos. 2010, 38, 732-739. [CrossRef] [PubMed]

42. Jang, H.H.; Ryu, S.H.; Le, T.K.; Doan, T.T.; Nguyen, T.H.; Park, K.D.; Yim, D.E.; Kim, D.H.; Kang, C.K.; Ahn, T;; et al. Regioselective C-H hydroxylation of omeprazole sulfide by Bacillus megaterium CYP102A1 to produce a human metabolite. Biotechnol. Lett. 2017, 39, 105-112. [CrossRef] [PubMed]

43. Omura, T.; Sato, R. The Carbon Monoxide-Binding Pigment of Liver Microsomes. II. Solubilization, Purification, and Properties. J. Biol. Chem. 1964, 239, 2379-2385. [PubMed]

44. Nguyen, N.A.; Jang, J.; Le, T.K.; Nguyen, T.H.H.; Woo, S.M.; Yoo, S.K.; Lee, Y.J.; Park, K.D.; Yeom, S.J.; Kim, G.J.; et al. Biocatalytic Production of a Potent Inhibitor of Adipocyte Differentiation from Phloretin Using Engineered CYP102A1. J. Agric. Food Chem. 2020, 68, 6683-6691. [CrossRef] [PubMed]

(C) 2020 by the authors. Licensee MDPI, Basel, Switzerland. This article is an open access article distributed under the terms and conditions of the Creative Commons Attribution (CC BY) license (http://creativecommons.org/licenses/by/4.0/). 